\title{
Profesor dr hab. med. Władysław Dobrzaniecki (1897-1941) — profesor Uniwersytetu Jana Kazimierza we Lwowie, prekursor chirurgii plastycznej i estetycznej w Polsce
}

Chirurgia plastyczna według prof. dr hab. dr h.c. Kazimierza Kobusa „zajmuje się korekcją zniekształceń wrodzonych, pourazowych, leczeniem schorzeń destrukcyjnych oraz leczeniem anomalii wymagających korekcji wyglądu i aparycji włącznie. Jest to ogromny obszar działania wymagający opanowania elementów wielu specjalności zarówno zabiegowych jak i nieinwazyjnych oraz nauk podstawowych" ". Profesor dr h.c. Kazimierz Kobus był wieloletnim dyrektorem chirurgii plastycznej Szpitala Chirurgii Plastycznej w Polanicy Zdroju i kierownikiem Kliniki Chirurgii Plastycznej Uniwersytetu Medycznego we Wrocławiu do 2008 roku. Jest znany w Europie i świecie.

Chirurgia plastyczna rozwinęła się niezwykle dopiero w latach siedemdziesiątych XX wieku, choć już w XIX wieku we Lwowie Grzegorz Ziembicki opisał przypadek wrodzonego zupełnego rozszczepu. Wcześniej operowano ze wskazań życiowych głównie rozszczepy podniebienia, wyrostka zębodołowego i warg. Są to: ,zabiegi wymagające doświadczenia wiedzy i precyzji. Wyniki można ocenić dopiero po zakończeniu wzrostu. Złe następstwa niewłaściwego operowania zostają na całe życie w postaci niedorozwojów i deformacji szczękowych, niezrozumiałej mowy i rażącego wyglądu"2.

Władysław Dobrzaniecki urodził się 24 września 1897 roku w Zielińcach, wsi sołeckiej w parafii Piłatkowice (gmina Jezierzany, powiat borszczowski,

1 K. Kobus, Ze skalpelem po świecie, Wrocław 2019, s. 148, 155-156.

2 G. Ziembicki, Przedstawienie chorego z zupetnym wrodzonym rozszczepem lewej połowy wargi górnej, podniebienia twardego i miękkiego, „Przegląd Lekarski” 36, 1897, nr 12, s. 154. 
dzisiejsza zachodnia Ukraina), gdzie jego ojciec był oficjalistą dworskim. W 1918 roku brał udział w obronie Lwowa.

Studiował na Uniwersytecie Jana Kazimierza we Lwowie, z przerwą jako uczestnik Armii Ochotniczej do udziału w wojnie polsko-bolszewickiej 1920 roku. W 1924 roku uzyskał dyplom doktora wszech nauk lekarskich. Razem z Tadeuszem Marciniakiem i Teofilem Zaleskim należał do Narodowej Demokracji. W latach 1924-1933 pracował jako asystent w Klinice Chirurgicznej kierowanej przez prof. Hilarego Schramma (1857-1940). Odbywał staże specjalizacyjne w Austrii, Niemczech, we Włoszech i Francji. Dłuższy czas pracował w Paryżu na oddziale chirurgii szczękowo-twarzowej prof. Leona Dufourmentela (1884-1957), ojca prof. Claude'a Dufourmentela (19152012), późniejszego twórcy Francuskiego Towarzystwa Chirurgii Plastycznej i Odtwórczej, oraz prof. Nöela Baurneta. W Strasburgu w klinice Renè Leriche'a przygotował rozprawę pod tytułem Obecny stan chirurgii układu współczulnego, na podstawie której habilitował się w 1931 roku u prof. H. Schramma.

W latach 1936-1938 był ordynatorem Państwowego Szpitala Powszechnego oraz Oddziału Chirurgii Szpitala Dziecięcego św. Zofii. We Lwowie przed wojną zoperowano urodzonego w 1929 roku chłopczyka Bogusia Schaeffera z powodu rozszczepu wargi, wyrostka zębodołowego i podniebienia $^{3}$. Najprawdopodobniej (przekaz rodzinny) była to operacja przeprowadzona przez prof. Władysława Dobrzanieckiego w szpitalu Dziecięcym św. Zofii. Dziecko po upiornych przeżyciach (wysłane na kolonie) samo przez Kazachstan wróciło po wojnie jako nastolatek do Polski. Po latach, badając pacjenta zewnątrzustnie, stwierdzono umiarkowany niedorozwój szczęki i lekkie porozszczepowe zniekształcenia nosa i wargi, wymowa była zrozumiała, lekko nosowa. Został profesorem kompozycji, dramaturgiem i był przeuroczym, dowcipnym człowiekiem, wykładowcą kompozycji w Krakowie i Salzburgu, kochanym przez studentów. Zmarł w 2019 roku.

Władysław Dobrzaniecki w 1939 roku został profesorem i kierownikiem Kliniki Chirurgii Uniwersytetu Jana Kazimierza. Po wybuchu II wojny światowej był komendantem Szpitala Wojskowego DOK6 we Lwowie i ordynatorem Polowego Szpitala Wojennego ${ }^{4}$.

Po wejściu Sowietów do Lwowa i utworzeniu Instytutu Medycznego został mianowany kierownikiem Szpitala Chirurgii. Od 23 września 1939 roku pracowała z prof. Dobrzanieckim na jego oddziale Jadwiga Bronisława Witkowska ps. Jagoda, sanitariuszka, która po maturze w 1937 roku ukończyła kursy ZHP przy Szkole Morskiej w Gdyni-Redłowie i asystowała z dr.

3 B. Bruziewicz-Mikłaszewska, informacja własna.

4 Biogram w J.B. Gliński, Słownik biograficzny lekarzy i farmaceutów, ofiar drugiej wojny światowej, Wrocław 1997, s. 69-70. 
Zbigniewem Drzewskim jako instrumentariuszka przy poważnych zabiegach operacyjnych z chirurgii ogólnej i plastycznej ${ }^{5}$.

Profesor dr hab. W. Dobrzaniecki ogłosił 50 prac naukowych z zakresu chirurgii plastycznej, chirurgii jamy brzusznej, urologii, transfuzjologii i chirurgii doświadczalnej, między innymi na temat sympatektomii periarterialnej. W dwóch przypadkach wykonał operację na zranionym sercu i przeprowadził operację wycięcia olbrzymiego tętniaka aorty szyjnej. W ramach badań anatomicznych zajmował się schorzeniami nerwu przedkrzyżowego i splotu podbrzusznego górnego. Był prekursorem polskiej kardiochirurgii i współczesnej chirurgii plastycznej.

Władysław Dobrzaniecki, aresztowany przez Niemców, został zamordowany przez Gestapo na Wzgórzach Wuleckich we Lwowie w grupie 25 profesorów lwowskich wyższych uczelni w nocy z 3 na 4 lipca 1941 roku. Zginął w wieku 44 lat.

Aresztowano go i rozstrzelano z przyjacielem, równolatkiem, doktorem praw Tadeuszem Tapkowskim i Eugeniuszem Kosteckim, mężem gospodyni domu profesora. Józefa Kostecka, która była w ciąży z późniejszym dr. Zbigniewem Kosteckim, zeznała że „hitlerowcy opróżnili kasę z biżuterii i dolarów, zabrali trzy pary irchowych rękawiczek i inne rzeczy, które zapakowali do walizki. W domu były antyki, dywany perskie, obrazy znanych malarzy polskich; wszystko zostało zrabowane i wywiezione trzeciego dnia po morderstwie"6.

Mieszkanie prof. Dobrzańskiego przy ulicy Romanowicza zajął Ukrainiec dr med. Wołodymyr Wreciono, brat Jewhena Wreciono, komendanta ukraińskiej policji we Lwowie (Z.A.), którego przyjacielem był Pieter Nicolas Menten (1899-1987), nikczemnik Holender?

Józefa Kostecka w swojej relacji z 6 września 1981 roku pisała:

z mego pokoju wzięli tylko obraz Kossaka „Orlęta lwowskie”, który dostałam na prezent ślubny od p. prof. Dobrzanieckiego [...] gdy się dowiedziałam, że oni już nie żyją, rozchorowałam się na nerki i do rozwiązania ciąży byłam na Łyczakowie w szpitalu. Opiekę miałam bardzo dobrą, bo tam byli lekarze, którzy mnie znali [...] tego samego roku urodziłam mego kochane-

5 Memoriał generał Marii Wittek, www.kpbc.umk.pl.

6 Relacja Józefy Sawickiej primo voto Kosteckiej z 6 września 1981 roku o aresztowaniach profesorów lwowskich w lipcu 1941 roku w: Kaźń profesorów lwowskich — lipiec 1941. Studia oraz relacje i dokumenty, zeb. i oprac. Z. Albert, Wrocław 1989, s. 352-354.

7 T. Cieszyński, Władysław Dobrzaniecki, [w:] Sylwetki chirurgów polskich, red. J. Bogusz, W. Rudowski, Wrocław 1982, s. 34; Kaźń profesorów..., s. 356; P. Schenk, Noc morderców. Kaźń polskich profesorów we Lwowie i holokaust w Galicji Wschodniej, przeł. P. Zarychta, Kraków 2012; Z. Kostecki, Czy ja jestem kresowiakiem?, „Nowa Trybuna Opolska” 18.11.2012; A. Biedrzycka, Kalendarium Lwowa 1918-1939, Kraków 2012, s. 225; T. Ceypek, Lwów w czasach trudnych. Notatki naocznego świadka, Kraków-Katowice 2011, s. 48; G. Mazur, J. Skwara, J. Węgierski, Kronika 2350 dni wojny i okupacji Lwowa 1 IX 1939-5 II 1946, Katowice 2007, s. 202, 204, 377.

Wrocławskie Studia Wschodnie 24, 2020

(C) for this edition by CNS 
go syna. Ważył niecałe dwa kilogramy, kości skórą pociągnięte. Położna, która go odbierała, mówiła, że przez 29 lat jej pracy pierwsze takie dziecko odbierała, ale pocieszała mnie, że bardzo zdrowe serce i płuca. Potrzeba mu tylko dużo ciepła. [...] Ja u p. profesora pracowałam od 1945 r. W 1939 roku w październiku wyszłam za mąż. Pan prof. był nam za świadka na takim małym przyjęciu i oczywiście na ślubie. Potem mieliśmy się wyprowadzić na Hołosko, bo męża siostra miała tam swój dom. Ale p. prof. bardzo nas prosił, żebyśmy go nie zostawiali samego. Mówił: „Macie gdzie mieszkać, co jeść, to po co macie iść na Hołosko? Jak się skończy wojna to ja Wam dam mieszkanie w mieście takie jakie zechcecie”. [...] Zdecydowaliśmy się zostać. On, to znaczy profesor, był dla nas bardzo dobry [...].

Zbigniew Kostecki, lek. med., urodził się 27 sierpnia 1941 roku we Lwowie (syn Eugeniusza i Józefy z domu Panek). Po wojnie zamieszkał z rodziną w Łańcucie. W latach 1961-1968 studiował medycynę w Śląskiej Akademii Medycznej w Katowicach. W latach 1969-1971 jako chirurg pracował w Szpitalu Powiatowym w Jarosławiu, a w latach 1971-1973 w Szpitalu Powiatowym w Koźlu. Po wyjeździe z Polski od 1973 roku pracował w Szpitalu Katolickim św. Elżbiety w Meersbuch-Lank w Niemczech. W 1976 roku przeniósł się do Szpitala Ewangelickiego w Düsseldorfie. W latach 1977-1980 pracował jako chirurg w klinice urazowej w Duisburg-Buchholz. Od 1981 roku prowadził prywatną praktykę lekarską w Krefeld i przyjmował na staż u siebie polskich studentów i młodych lekarzy. Od 1975 roku był aktywnym członkiem organizacji polonijnych w Niemczech, między innymi od 1992 roku był prezesem Polskiego Towarzystwa Medycznego w Niemczech i nawiązał kontakty z Dolnośląską Izbą Lekarską. Od 1993 roku był członkiem Kongresu Polonii Niemieckiej. Jest autorem wielu artykułów z zakresu ochrony zdrowia w prasie medycznej i twórcą stron internetowych dla Polonii ${ }^{8}$.

$\mathrm{Na}$ fasadzie gmachu Uniwersytetu Jana Kazimierza we Lwowie jest napis: „Patriae decori civibus educandis” — „Wykształceni obywatele są ozdobą ojczyzny". I taką ozdobą był prof. dr hab. Władysław Dobrzaniecki! A ile mógłby jeszcze dokonać, gdyby żył!

We Lwowie 4 lipca 2011 roku odsłonięto nowy pomnik pomordowanych polskich profesorów. Do dziś nie ma na nim pełnej listy tych, którzy zginęli na Wzgórzach Wuleckich. Zbrodnia ta nie została nawet nazwana przez historię, a morderców nigdy nie ukarano.

Zbigniew Kostecki, dr med. emerytowany lekarz chirurg, który wiele lat przepracował w Niemczech, a urodził się 1941 roku jako pogrobowiec, syn Eugeniusza Kosteckiego, 4 lipca 2011 roku we Lwowie, poczuł się całkowicie zignorowany i niepotrzebny na tej uroczystości.

Ta uroczystość bardzo mnie rozżaliła. Szczególnie jeśli chodzi o prezydenta Wrocławia, Rafała Dutkiewicza, który w całej tej uroczystości i przy tylu przemówieniach nie znalazł nawet dwóch minut, żeby mogły się wypowiedzieć rodziny pomordowanych. [...] Nie dopusz-

8 „Forum Polonijne” 1996, nr 3.

Wrocławskie Studia Wschodnie 24, 2020

(C) for this edition by CNS 
czono do głosu także niemieckiego historyka, który napisał i wydał w Niemczech książkę o tej niemieckiej zbrodni. Dieter Schenk, syn gestapowca, przyjechał tutaj, aby uklęknąć przed pomnikiem i publicznie wyznać winę swoich współziomków. Niestety, nikt mu na to nie pozwolił: ani prezydent Wrocławia, ani mer Lwowa ${ }^{9}$.

Profesor Dobrzaniecki pozostawił po sobie ślad i należy mu się pamięć, a dr Zbigniew Kostecki o nią dba!

Non omnis moriar!

\section{Bibliografia}

Biedrzycka A., Kalendarium Lwowa 1918-1939, Kraków 2012.

Borzęcki J., Skandaliczne przemówienie i zakazane słowo „polskich”, „Kurier Galicyjski” 15-28.07.2011, www.kuriergalicyjski.com.

Ceypek T., Lwów w czasach trudnych. Notatki naocznego świadka, Kraków-Katowice 2011.

Cieszyński T., Władysław Dobrzaniecki, [w:] Sylwetki chirurgów polskich, red. J. Bogusz,

W. Rudowski, Wrocław 1982.

„Forum Polonijne” 1996, nr 3.

Gliński J.B., Stownik biograficzny lekarzy i farmaceutów, ofiar drugiej wojny światowej, Wrocław 1997.

Kaźń profesorów lwowskich - lipiec 1941. Studia oraz relacje i dokumenty, zeb. i oprac. Z. Albert, Wrocław 1989.

Kobus K., Ze skalpelem po świecie, Wrocław 2019.

Kostecki Z., Czy ja jestem kresowiakiem?, „Nowa Trybuna Opolska” 18.11.2012.

Mazur G., Skwara J., Węgierski J., Kronika 2350 dni wojny i okupacji Lwowa 1 IX 1939-5 II 1946, Katowice 2007.

Memoriał generał Marii Wittek, www.kpbc.umk.pl.

Nespiak D., Tadeusz Ostrowski, „Wrocławskie Studia Wschodnie” 22, 2018.

Relacja Józefy Sawickiej primo voto Kosteckiej z 6 września 1981 roku o aresztowaniach profesorów lwowskich w lipcu 1941 roku, [w:] Kaźn profesorów lwowskich - lipiec 1941. Studia oraz relacje i dokumenty, zeb. i oprac. Z. Albert, Wrocław 1989.

Schenk P., Noc morderców. Kaźń polskich profesorów we Lwowie i holokaust w Galicji Wschodniej, przeł. P. Zarychta, Kraków 2012.

Ziembicki G., Przedstawienie chorego z zupetnym wrodzonym rozszczepem lewej połowy wargi górnej, podniebienia twardego i miękkiego, „Przegląd Lekarski” 36, 1897, nr 12.

9 J. Borzęcki, Skandaliczne przemówienie i zakazane słowo „,polskich”, „Kurier Galicyjski" 15-28.07.2011, www.kuriergalicyjski.com (dostęp: 30.04.2020). 